\title{
Tinjauan Komprehensif atas Peraturan Pembatasan Interest Deductions and Other Financial Payments di Indonesia
}

\author{
Nurul Ismah ${ }^{\mathrm{a}}$ dan Agustin Setya Ningrum ${ }^{\mathrm{b} *}$ \\ ${ }^{a}$ Fakultas Ekonomi dan Bisnis, Universitas Indonesia, nurul.ismah90@gmail.com, Indonesia \\ ${ }^{a}$ Fakultas Ekonomi dan Bisnis, Universitas Indonesia, setyaningrum@ui.ac.id, Indonesia
}

\begin{abstract}
Tujuan penelitian ini adalah meninjau aspek dalam BEPS Action Plan 4 yang direkomendasikan oleh OECD dan G20 terhadap peraturan terkait pembatasan interest deductions and other financial payments di Indonesia. Penelitian ini juga membandingkan aspek tersebut dengan negara-negara OECD dan G20 serta mengidentifikasi potensi penerapan BEPS Action Plan 4 dalam mengatasi base erosion and profit shifting. Penelitian bersifat analisis kualitatif deskriptif, yang dilakukan melalui wawancara, tinjauan literatur, dan simulasi perhitungan potensi penerapan BEPS Action Plan 4 dengan menggunakan data wajib pajak tahun 2015. Berdasarkan hasil penelitian disimpulkan bahwa peraturan pembatasan interest deductions and other financial payments di Indonesia sudah memenuhi 6 dari 7 aspek, tetapi dalam bentuk pendekatan berbeda. Peraturan perpajakan negara-negara yang ditinjau telah memenuhi aspek-aspek tersebut dengan penyesuaian karakteristik negara. Kombinasi antara fixed ratio melalui DER dan BEPS Action Plan 4 dapat mengatasi praktik BEPS dengan lebih baik karena saling menutupi kelemahan masing-masing pendekatan. Komitmen mengadopsi rekomendasi best practice diperlukan demi terwujudnya kesamaan perlakuan perpajakan melalui harmonisasi peraturan perpajakan di Indonesia dan negara lainnya.
\end{abstract}

Keywords: Base Erosion and Profit Shifting; Debt Shifting; Interest Deductions and Other Financial Payments; Pajak Internasional; Thin Capitalization.

*Corresponding author. E-mail: setyaningrum@ui.ac.id. 


\section{Pendahuluan}

Potensi penghindaran pajak terlihat pada perilaku wajib pajak yang menggeser labanya dari high-tax country ke low-tax country (Bartelsman dan Beetsma, 2003), agar memperoleh tarif pajak yang lebih rendah. Penggeseran penghasilan tersebut menyebabkan terjadinya penggerusan basis pemajakan pada negara sumber. Hal ini dibuktikan dengan menurunnya corporate effective tax rates (ETRs) dan meningkatnya jumlah perusahaan yang melaporkan kewajiban perpajakannya nihil (ATO, 2010). Praktik ini umumnya terjadi pada perusahaan multinasional (penanaman modal asing (PMA)) ${ }^{1}$. Kerugian PMA tersebut diindikasikan bukan dari operasionalnya melainkan dari biaya bunga dan biaya-biaya lainnya.

Cara yang paling sederhana dan banyak ditemui untuk melakukan penggerusan basis pemajakan adalah melalui biaya bunga pinjaman (Burnett, 2015). Motifnya adalah untuk mendapatkan insentif dan kesempatan menggeser profitnya dari negara dengan tarif pajak tinggi (high-tax country) ke negara dengan tarif pajak rendah (low-tax country) (Haufler dan Runkel, 2009). Praktik ini didukung dengan fleksibilitas yang dimiliki perusahaan multinasional dalam menempatkan debt pada high-tax country (Yoshihiro, 2014). Implikasinya, perusahaan multinasional dapat menaikkan utangnya sampai dengan batas maksimum tanpa dikenakan pajak (Egger, et.al., 2009).

Praktik penggandaan debt tersebut menyebabkan terjadinya penggerusan basis perpajakan domestik dan pergeseran keuntungan di berbagai negara. Hal ini memicu isu base erosion and profit shifting (BEPS) mencuat dalam forum-forum publik internasional, seperti Organization for Economic Cooperation and Development (OECD) dan G20. Dari forum tersebut dirumuskan 15 Action Plan untuk mengatasi praktik BEPS tersebut. Salah satunya adalah Action Plan 4: Limiting Base Erosion Involving Interest Deductions and Other Financial Payments. Action Plan tersebut bersifat rekomendasi best practice untuk menyusun ketentuan yang mencegah penggerusan basis perpajakan melalui pembatasan terhadap biaya bunga dan pembayaran biaya finansial lainnya. Indonesia, sebagai anggota

\footnotetext{
1 Menteri Keuangan menyatakan bahwa sekitar 2.000 PMA tidak membayar pajak dalam 10 tahun terakhir karena mengklaim perusahaan tersebut selalu merugi (Jefriando, 2016, http://finance.detik.com/beritaekonomi-bisnis/d-3170629/2000-perusahaan-asing-tak-bayar-pajak-negararugi-rp-500-t. 22 Maret 2016)
}

G20 dan associate member dalam BEPS Project, ikut bertanggung jawab dalam melaksanakan Action Plan tersebut.

Sebelum tahun 2015, Direktorat Jenderal Pajak (DJP) sebagai otoritas perpajakan di Indonesia menggunakan pendekatan berdasarkan Pasal 18 ayat (1) dan ayat (3) Undang-Undang Nomor 7 Tahun 1983 sebagaimana sudah diganti dengan (stdd) Undang-Undang Nomor 36 Tahun 2008 tentang Pajak Penghasilan (yang selanjutnya disebut UU $\mathrm{PPh}$ ) dalam menghadapi kasus sengketa terkait pembatasan biaya bunga dan biaya finansial lainnya. Pendekatan dengan Pasal 18 ayat (1) UU $\mathrm{PPh}$ dianggap tidak memiliki dasar hukum yang kuat karena belum dilaksanakannya amanat untuk menetapkan rasio utang terhadap modal oleh Menteri Keuangan.

Selain itu, berdasarkan pengamatan pra-penelitian, terdapat 76 wajib pajak yang melaporkan rugi selama 5 tahun berturut-turut. Dari pengamatan tersebut diketahui bahwa terdapat 19 wajib pajak yang kerugiannya bukan bersumber dari kegiatan operasional, melainkan dari biaya bunga pinjaman. Hal ini terlihat dari biaya bunga wajib pajak yang melebihi pendapatan sebelum pajak, bunga, penyusutan dan amortisasi (EBITDA). Faktanya, wajib pajak tersebut masih eksis beroperasi di Indonesia, tetapi tidak pernah membayar pajak.

Kemudian, pengamatan pra-penelitian juga dilakukan terhadap 413 wajib pajak yang melaporkan rugi pada tahun 2015. Dari pengamatan tersebut terdapat wajib pajak yang DER-nya di atas 10:1. Hal ini mengindikasikan bahwa wajib pajak mendanai usahanya dari utang, bukan dari modal. Kondisi tersebut dapat membahayakan wajib pajak dari risiko kebangkrutan.

Sebagai manifestasi dari keseriusan untuk menghindari praktik yang tidak sehat, pemerintah menetapkan Peraturan Menteri Keuangan Nomor 169/PMK.010/2015 tentang Penentuan Besarnya Perbandingan Antara Utang dan Modal Perusahaan untuk Keperluan Penghitungan Pajak Penghasilan. PMK 169/2015 tersebut memiliki kesamaan tujuan dengan BEPS Project Action Plan Nomor 4: Limiting Base Erosion Involving Interest Deductions and Other Financial Payments, yaitu membatasi biaya bunga yang diperhitungkan dalam menghitung penghasilan kena pajak.

Hal ini menjawab kekhawatiran dari penelitianpenelitian terdahulu. Penelitian yang dilakukan oleh Saleh (2003) misalnya, menyimpulkan bahwa terdapat praktik minimalisasi modal dilakukan wajib pajak sebagai upaya penghindaran kewajiban 
perpajakan di Indonesia. Hal tersebut dapat terlihat pada skema pinjaman antar related party (Prasetyo, 2007), karena relatif lebih mudah dilakukan dengan memanfaatkan loophole dari peraturan perpajakan yang berlaku (Siahaan, 2010). Berbeda dengan hasil penelitian-penelitian tersebut, penelitian yang dilakukan oleh Harisman (2014) dan Christiana (2015) menyimpulkan bahwa belum ditemukannya upaya penghindaran pajak melalui peningkatan DER pada perusahaan terbuka. Isu ini terus diteliti karena belum adanya kepastian hukum terkait dengan DER yang digunakan dalam penghitungan pajak penghasilan pada saat itu. Penelitian yang dilakukan oleh Siregar (2007), Siahaan (2010), Alhusnieka (2011) dan Hartono (2014) disarankan agar amanat Pasal 18 ayat (1) UU PPh tersebut segera dilaksanakan, sehingga praktik penghindaran pajak dapat dengan mudah diidentifikasi.

Berdasarkan gambaran kondisi di atas, maka penelitian ini dilakukan dengan tiga tujuan. Pertama adalah meninjau secara kompehensif peraturan pembatasan interest deductions and other financial payments di Indonesia melalui pendekatan DER yang berlaku di Indonesia dengan diterbitkannya PMK 169/PMK.010/2015. Tinjauan akan berdasarkan aspek-aspek dalam BEPS Action Plan 4. Selain itu, penelitian ini juga dimaksudkan untuk membandingkan peraturan pembatasan interest deductions and other financial payments yang berlaku di Indonesia, negara-negara anggota OECD dan G20 lainnya serta best practice yang direkomendasikan oleh OECD dan G20. Tujuan terakhir adalah melihat potensi penerapan BEPS Action Plan 4 tersebut dalam mengatasi praktik BEPS di Indonesia.

Berbeda dengan penelitian sebelumnya, dalam penelitian ini Indonesia telah menetapkan tingkat utang yang berpotensi sebagai upaya penghindaran pajak dan menggerus basis pemajakan. Selain itu, penelitian ini juga memberikan gambaran terkait peraturan yang berlaku di Indonesia dalam memenuhi aspek-aspek yang direkomendasikan dalam BEPS Action Plan 4. Hal ini belum pernah dilakukan dalam penelitian sebelumnya.

\section{Kajian Literatur}

Thin Capitalization dan Hubungannya dengan Transfer Pricing

Pada umumnya, peraturan perpajakan memperbolehkan biaya bunga dijadikan sebagai unsur pengurang (deductible expense) dalam menghitung penghasilan kena pajak, tetapi tidak dengan dividen. Perbedaan perlakuan antara dividen dan biaya bunga tersebut mendorong terjadinya praktik thin capitalization (Kurniawan, 2010). Thin capitalization adalah praktik di perusahaan memiliki modal yang tipis, karena sebagian besar pembiayaannya bersumber dari utang. Dengan memanfaatkan perbedaan perlakuan tersebut, perusahaan menyusun strategi yang berdampak signifikan terhadap tingkat keuntungan yang dilaporkan untuk keperluan perpajakan. Perusahaan multinasional lebih leluasa menentukan harga transfer tingkat bunga dalam intracompany loan. Semakin tinggi tingkat bunga, semakin tinggi biaya bunga sebagai pengurang pajak, semakin rendah pajak yang dibayarkan. Untuk tujuan penghematan pajak, utang menjadi lebih efektif daripada modal (OECD, 2012).

\section{Prinsip dan Asas dalam Perpajakan Internasional}

Setiap negara memiliki kedaulatan dalam memajaki penduduk maupun bukan penduduk yang ada di negaranya berdasarkan prinsip yang dianut masing-masing negara. Perbedaan prinsip tersebut memunculkan isu pemajakan berganda internasional yang dikhawatirkan dapat menghambat kegiatan ekonomi. Dibutuhkan perhatian khusus untuk mengatasi kekhawatiran tersebut. Menurut Soemitro (1986) dalam Mightyn (2015), ada beberapa prinsip dan asas hukum pajak internasional. Prinsip tersebut terdiri atas prinsip kedaulatan, keadilan, negara hukum, teritorial/wilayah, universalitas. Sementara itu, asas yang diterapkan meliputi asas negara tempat tinggal, negara asal/sumber, kebangsaan, dan pendirian tetap (Permanent Establishment (PE)/Badan Usaha Tetap (BUT))

\section{Tax Avoidance dan Base Erosion and Profit Shifting} (BEPS)

Suatu transaksi dikategorikan unacceptable tax avoidance memiliki karakteristik: (i) tidak memiliki tujuan usaha yang baik; (ii) semata-mata untuk menghindari pajak; (iii) tidak sesuai dengan spirit dan intention of parliament; dan (iv) adanya transaksi yang direkayasa agar menimbulkan biaya-biaya atau kerugian. Selain tax avoidance, muncul istilah baru base erosion and profit shifting (BEPS). Menurut OECD (2013a), BEPS merupakan sebuah strategi perencanaan pajak yang mengeksploitasi celah dan 
ketidaksesuaian dalam peraturan perpajakan. Wajib pajak dapat menggeser atau mengalihkan keuntungan melalui cara yang artifisial dari negara dengan tarif pajak tinggi (high-tax country) ke negara dengan tarif pajak yang rendah (low-tax country) atau bahkan nol (zero-tax country).

\section{Rekomendasi BEPS Action Plan 4: Limiting Interest Deductions and Other Financial Payments (OECD/G20)}

Rekomendasi BEPS Action Plan 4 tersebut dapat difokuskan ke dalam 10 aspek, berikut ini:

a. Definisi biaya bunga dan biaya bunga lainnya OECD dan G20 mendefinisikan biaya bunga yang dibatasi harus mencakup segala bentuk biaya pinjaman atau biaya finansial lainnya yang setara dengan biaya bunga, seperti komponen pendanaan dalam sewa pembiayaan, kapitalisasi biaya bunga yang ditambahkan ke nilai aset terkait, dan keuntungan atau kerugian perubahan kurs atas pinjaman dalam mata uang asing.

b. Entitas yang diberlakukan ketentuan pembatasan biaya bunga

Setiap entitas memiliki risiko yang berbeda-beda, sehingga diperlukan ambang batas minimum (de minimis treshold) sebagai filter pertama untuk mengatasi BEPS. Ambang batas minimum yaitu ambang batas dimana perusahaan dianggap berisiko rendah untuk melakukan praktik penghindaran pajak. Ambang batas tersebut diterapkan terhadap jumlah total beban bunga bersih yang dibebankan perusahaan.

c. Dasar pendekatan terbaik

Dasar pendekatan yang direkomendasikan adalah langsung menggunakan tingkat biaya bunga yang dapat dikurangkan dalam menghitung penghasilan kena pajak. Pendekatan yang berdasarkan biaya bunga juga dapat mengantisipasi risiko adanya interest rate yang tidak wajar yang sulit untuk dilakukan pengujian.

d. Pengukuran aktivitas ekonomi

Pengukuran aktivitas ekonomi berdasarkan nilai aktiva memiliki kelebihan lebih stabil dan compliance cost-nya rendah. Namun pendekatan ini tidak dapat membatasi entitas yang rugi. Artinya, entitas yang mengakui rugi tetap dapat mengurangi biaya bunganya. Oleh karena itu, pengukuran aktivitas ekonomi melalui pendapatan lebih direkomendasikan dalam BEPS Action Plan 4 dan karenanya hanya perusahaan yang earningnya positif yang dapat membiayakan biaya bunga. e. Fixed Ratio Rules (FRR)

Pendekatan fixed ratio rules (FRR) diukur dengan menggunakan pembatasan persentase tertentu biaya bunga bersih terhadap profit atau pendapatan sebelum bunga, pajak, depresiasi dan amortisasi (earning before interest, taxes, depreciation and amortisation (EBITDA)) berdasarkan pelaporan fiskal. Karenanya, pengukuran ini dapat dihubungkan langsung dengan penghasilan kena pajak entitas. Persentase rasio biaya bunga terhadap EBITDA yang direkomendasikan dalam BEPS Action Plan 4 yaitu rentang $10 \%$ s.d. $30 \%$. Atas entitas yang melebihi rasio yang ditentukan maka porsi biaya bunga yang diperkenankan sebagai pengurang pajak maksimal hanya sebatas rasio yang ditetapkan, dan atas kelebihan biaya bunga yang melewati rasio tidak dapat dijadikan sebagai pengurang pajak.

Walaupun mudah digunakan, FRR masih tumpul untuk mengatasi fakta bahwa operasi perusahaan multinasional yang mempunyai beragam sektor, memiliki tingkat leverage yang bervariasi. Pada sektor tertentu tingkat leverage-nya mungkin rendah, namun di sektor lain mungkin tingkat leverage-nya tinggi. Tinggi rendahnya tingkat leverage mungkin bukan hanya disengaja untuk kepentingan perpajakan semata, melainkan juga untuk kepentingan ekonomi. Karenanya, masih diperlukan kombinasi antara FRR dengan group ratio rules.

f. Group Ratio Rules (GRR)

Uji GRR direkomendasikan sebagai tahapan berikutnya setelah fixed ratio rules. Uji ini diberlakukan kepada entitas yang melebihi ambang batas FRR agar tetap diperbolehkan mengurangkan biaya bunga dari penghasilan kena pajak menggunakan GRR. Tetapi, biaya bunga yang direkomendasikan tidak lebih dari $10 \%$ group ratio. Pengukurannya menggunakan rasio biaya bunga terhadap pihak ketiga bersih terhadap EBITDA konsolidasi group. Apabila rasio tersebut lebih dari batas yang ditentukan, maka biaya bunga pada pihak ketiga yang dapat dijadikan pengurang pajak hanya sebesar porsi maksimum group ratio.

g. Mengatasi volatilitas dan perpajakan berganda Tingkat pendapatan sangat dipengaruhi oleh aktivitas perekenomian di suatu negara. Selain itu, pembatasan bunga memiliki isu perpajakan berganda yang harus diperhatikan oleh setiap negara, yaitu ketika beban bunga yang menjadi objek pajak di suatu negara dibatasi, apakah 
pendapatan bagi negara yang menerima pendapatan bunga dipajaki secara penuh, atau hanya sebatas yang dibiayakan oleh debitur.

Untuk mengatasi volatilitas tersebut, BEPS Action Plan 4 merekomendasikan agar menggunakan EBITDA rata-rata dari beberapa tahun, atau memperbolehkan kompensasi atas biaya bunga yang tidak dapat dibiayakan pada tahun pajak pelaporan dan kapasitas biaya bunga yang belum terpakai karena masih di bawah rasio agar dapat dikompensasikan ke tahun pajak berikutnya.

h. Tujuan peraturan

Agar dapat membatasi biaya bunga yang berlebihan dengan efektif, peraturan yang dibuat harus bertujuan untuk membatasi langsung biaya bunga. Oleh karena itu, direkomendasikan agar setiap negara membuat peraturan khusus yang mereduksi risiko penghindaran pajak dan praktik BEPS.

i. Penerapan pendekatan terbaik bagi kelompok perbankan dan asuransi

BEPS Action Plan ke-4 juga menyatakan bahwa harus ada fitur tertentu yang dapat digunakan dengan efektif untuk mengatasi penggerusan basis pemajakan dan pergeseran laba di sektor perbankan dan asuransi. Hal ini dikarenakan kedua industri tersebut memiliki proses bisnis yang berbeda dari sektor lainnya. Di kedua industri tersebut, uji FRR dan GRR dinilai kurang efektif. OECD dan negara-negara G20 masih melakukan kajian yang diharapkan selesai dalam tahun 2016 untuk memberikan rekomendasi pendekatan tertentu atas sektor perbankan dan asuransi.

j. Penerapan pendekatan terbaik

Yang perlu diperhatikan dalam aspek ini adalah bagaimana penerapan pembatasan intertest deductions dan other financial payments dapat berkoordinasi dan berinteraksi dengan BEPS Action Plan lainnya.

\section{Ketentuan Pajak Penghasilan Terkait Pembatasan Interest Deductions dan Other Financial Payments di Indonesia}

Pada 8 Oktober 1984, Menteri Keuangan mengeluarkan Keputusan Menteri Keuangan (KMK) Nomor 1002/KMK.04/1984 tentang Penentuan Perbandingan Antara Hutang dan Modal Sendiri Untuk Keperluan Pengenaan Pajak Penghasilan. Dalam KMK tersebut diatur bahwa angka DER perusahaan setinggi-tingginya adalah tiga dibanding satu (3:1). Namun, lima bulan kemudian, yaitu pada tanggal 8 Maret 1985, KMK tersebut ditunda pemberlakuannya. Penundaan ini didasarkan pada pertimbangan bahwa dengan penentuan batasan DER tersebut dikhawatirkan akan menghambat perkembangan dunia usaha, sehingga pelaksanaan KMK.1002/KMK.04/1984 dirasa perlu untuk ditangguhkan.

Tiga dekade kemudian, yaitu pada tanggal 9 September 2015, diterbitkan kembali Peraturan Menteri Keuangan Nomor 169/PMK.010/2015 tentang Penentuan Besarnya Perbandingan Antara Utang dan Modal Perusahaan untuk Keperluan Penghitungan Pajak Penghasilan. Peraturan Menteri Keuangan ini diterbitkan untuk keperluan penghitungan Pajak Penghasilan bagi Wajib Pajak badan yang didirikan atau bertempat kedudukan di Indonesia yang modalnya terbagi atas saham-saham. Besarnya DER ditetapkan paling tinggi empat banding satu (4:1). Utang dalam Peraturan Menteri Keuangan ini didefiisikan sebagai saldo rata-rata utang pada satu tahun pajak atau bagian tahun pajak, yang dihitung berdasarkan saldo utang rata-rata tiap akhir bulan pada bagian tahun pajak atau tahun pajak yang bersangkutan. Sementara yang dimaksud dengan modal adalah rata-rata saldo modal tiap akhir bulan pada tahun pajak atau pada bagian akhir tahun pajak yang bersangkutan, yang meliputi ekuitas sebagaimana dimaksud dalam standar akuntansi keuangan yang berlaku umum dan pinjaman tanpa bunga dari pihak yang memiliki hubungan istimewa.

PMK mengenai pembatasan DER perusahaan ini mengecualikan wajib pajak bank; lembaga pembiayaan; asuransi dan reasuransi; industri pertambangan minyak dan gas bumi, pertambangan umum, dan pertambangan lainnya yang terikat kontrak bagi hasil, kontrak karya, atau perjanjian kerja sama pengusahaan pertambangan, dan dalam kontrak atau perjanjian dimaksud mengatur atau mencantumkan ketentuan mengenai batasan perbandingan antara utang dan modal; Wajib Pajak yang seluruh penghasilannya dikenai Pajak Penghasilan yang bersifat final berdasarkan peraturan perundang-undangan sendiri; dan Wajib Pajak yang menjalankan usaha di bidang infrastruktur.

Dalam hal besarnya DER melebihi 4:1, maka biaya pinjaman yang dapat dijadikan sebagai pengurang pajak hanya sebesar biaya pinjaman sesuai dengan porsi DER. Yang termasuk dalam lingkup biaya pinjaman yang dimaksud, yaitu bunga pinjaman, diskonto premium yang terkait dengan pinjaman, biaya tambahan yang terjadi yang terkait dengan perolehan pinjaman (arrangement of 
borrowings), beban keuangan dalam sewa pembiayaan, biaya imbalan karena jaminan pengembalian utang, dan selisih kurs yang berasal dari pinjaman dalam mata uang asing sepanjang selisih kurs tersebut sebagai penyesuaian terhadap biaya bunga dan biaya lainnya.

Dalam hal Wajib Pajak memiliki utang kepada pihak yang memiliki hubungan istimewa, maka biaya pinjaman atas utang tersebut harus memenuhi ketentuan Pasal 6 dan Pasal 9 UU PPh dan prinsip kewajaran dan kelaziman usaha sebagaimana yang dimaksud pasal 18 ayat (3) UU PPh. Selain itu, apabila Wajib Pajak memiliki saldo ekuitas nol, maka seluruh biaya pinjaman tidak dapat diperhitungkan dalam penghitungan penghasilan kena pajak.

Di samping itu, Wajib Pajak yang mempunyai utang swasta luar negeri diwajibkan untuk menyampaikan laporan terkait besarnya utang swasta luar negeri tersebut kepada Direktur Jenderal Pajak melalui tata cara yang diatur dalam Peraturan Direktur Jenderal Pajak. Apabila laporan tersebut tidak disampaikan, maka biaya pinjaman yang terutang dari utang swasta luar negeri tersebut tidak dapat dijadikan sebagai pengurang dalam menghitung penghasilan kena pajak.

\section{Metode Penelitian}

Untuk mencapai rumusan permasalahan pertama dalam penelitian ini, maka akan dilakukan tinjauan secara komprehensif terhadap peraturan pembatasan interest deductions and other financial payments di Indonesia melalui pendekatan DER yang mulai berlaku setelah diterbitkannya PMK 169/PMK.010/2015, tinjauan akan berdasarkan aspek-aspek dalam BEPS Action Plan 4. Langkah pertama yaitu tersebut digunakan metode yang terdiri dari pengkategorian aspek-aspek dalam BEPS Action Plan 4 ke dalam aspek-aspek yang akan ditinjau dalam penelitian dan pemilihan responden untuk wawancara. Untuk mempermudah pembahasan, penelitian ini akan meninjau literatur peraturan ke dalam 7 aspek berikut ini:

a. Pendekatan yang digunakan. Aspek ini mencakup aspek entitas yang memiliki risiko rendah sehingga diberlakukan de minimis treshold, pendekatan FRR, pendekatan GRR, dan pendekatan lainnya yang dimaksudkan untuk mengatasi volatilitas dan perpajakan berganda dalam satu kesatuan pendekatan. Penggabungan aspek ini diharapkan dapat menggambarkan secara menyeluruh terkait pendekatan yang direkomendasikan dalam BEPS Action Plan 4.

b. Definisi elemen rasio. Aspek ini merupakan perpanjangan dari aspek dasar pengukuran terbaik. Setiap negara memiliki perbedaan dalam mendefinisikan elemen rasio berdasarkan interest expense terhadap EBITDA, maupun DER yang digunakan dalam penghitungan rasio tersebut.

c. Entitas yang diberlakukan dan dikecualikan. Aspek ini mendefinisikan entitas yang diberlakukan dan dikecualikan dari pembatasan biaya bunga, termasuk perlakuan pada aspek perbankan dan asuransi.

d. Pengukuran aktivitas ekonomi entitas. Aspek ini untuk memberikan gambaran preferensi pengukuran aktivitas ekonomi entitas yang diterapkan.

e. Definisi dari biaya bunga dan pembayaran lainnya yang secara ekonomis setara dengan biaya bunga. Aspek ini penting untuk mengetahui sejauh mana biaya bunga yang dibatasi dalam BEPS Action Plan 4, Indonesia, dan negara lainya.

f. Tujuan penerapan pembatasan interest deductions and other financial payments. Aspek ini merupakan perpajangan dari aspek tujuan peraturan.

g. Ketentuan khusus lainnya yang berkaitan dengan pembatasan biaya bunga tersebut. Aspek ini untuk membahas adanya aturan khusus yang diperlakukan masing-masing negara untuk mengatasi pembatasan biaya bunga yang tidak dapat diatur secara umum. Dengan aspek ini dapat diketahui adanya harmonisasi peraturan di masing-masing negara, dan kesesuaiannya dengan rekomendasi dalam BEPS Action Plan 4.

Selain itu, untuk menjawab permasalahan 1, juga dilakukan wawancara yang mendalam kepada pihakpihak terkait dan peninjauan makalah terkait. Wawancara dilakukan dengan Badan Kebijakan Fiskal (BKF) dalam kapasitasnya sebagai institusi yang berwenang atas ketentuan perpajakan terkait kebijakan fiskal di Indonesia yang diwakili oleh Syarif Ibrahim Busono Adi selaku Kepala Subbidang PPh Umum, DJP dalam kapasitasnya sebagai otoritas perpajakan di Indonesia diwakili oleh Bapak Ibnu Wijaya, dan pihak akademisi sebagai pihak independen untuk mencari masukan lain terkait ketentuan pembatasan interest deduction and other financial payments di Indonesia. Untuk wawancara dengan akademisi dilakukan dengan Bapak Anung Andang Wiratama dan Bapak Anang Mury Kurniawan. 
Berikut pertanyaan yang ditanyakan dalam wawancara:

a. Bagaimana pendapat Bapak tentang praktik penggerusan basis pemajakan dan pergeseran laba (base erosion and profit shifting/BEPS) di Indonesia? Termasuk dalam acceptable tax avoidance atau unacceptable tax avoidance?

b. Menurut Bapak, praktik BEPS yang paling sering terjadi di Indonesia dengan skema apa?

c. Apa saja kesulitan untuk mengatasi praktik BEPS umumnya? dan Praktik BEPS melalui biaya bunga yang berlebihan pada khususnya?

d. Apakah Bapak sudah mendengar tentang BEPS Action Plan yang dirumuskan oleh member OECD dan negara-negara G20?

e. Bagaimana pendapat Bapak dengan BEPS Action Plan No. 4: Limiting Base Erosion Involving Interest Deductions and Other Financial Payments? apakah rekomendasi BEPS Action Plan tersebut dapat dikatakan sebagai best practise?

f. Menurut Bapak, dengan diterbitkannya PMK 169/PMK.010/2015 apakah sudah sesuai dengan rekomendasi BEPS Action Plan No.4 tersebut untuk mengatasi BEPS di Indonesia?

g. Bagaimana pendapat Bapak terkait definisi utang dan modal dalam PMK 169/PMK.010/2015?

h. Terkait dengan biaya bunga yang tidak dapat diberlakukan sebagai pengurang pajak pada PMK 169/PMK.010/2015 tersebut, apakah sudah didefinisikan dengan cukup baik?

i. Apakah masih terdapat biaya bunga terkait dengan BEPS Action Plan No.4 yang belum termasuk dalam definisi PMK 169/PMK.010/2015?

j. Menurut pandangan Bapak, dimana poin penting yang menjadi kunci PMK 169/PMK.010/2015 ini untuk mengatasi BEPS?

k. Bagaimana dengan pembatasan bunga untuk Wajib Pajak yang dikecualikan dalam PMK 169/PMK.010/2015?

1. Menurut Bapak, negara member OECD dan G20 mana yang dapat dijadikan benchmark Indonesia dalam menerapkan BEPS Action Plan No.4?

m. Bagaimana ada aspek perpajakan berganda dalam pembatasan biaya bunga pada BEPS Action Plan No.4?

n. Bagaimana dengan target dari diterapkannya PMK 169/PMK.010/2010 secara umumnya? dan khususnya terhadap praktik BEPS?

Selain wawancara, juga dilakukan peninjauan makalah yang dipublikasikan oleh Darussalam dan
Kristiaji (2015) di Danny-Darussalam Tax Center (DDTC).

Perumusan masalah kedua dapat dijawab dengan membandingkan aspek yang ditinjau dalam rumusan masalah 1 terhadap peraturan perpajakan yang berlaku di Indonesia, negara OECD dan G20, serta best practice yang direkomendasikan oleh OECD dan G20. Untuk mempersempit pembahasan, terpilihlah 5 sampel negara dengan alasan sebagai berikut:

a. Australia, menurut Amin (2013) dalam Hartono (2014), negara member OECD ini memiliki karakteristik yang mirip dengan Indonesia, yaitu wilayah negaranya yang luas, kekayaan sumber daya alam berupa hasil perkebunan, peternakan dan tambang, serta bukan negara industri jasa.

b. Jepang dipilih karena berdasarkan data statistik utang luar negeri swasta yang dipublikasikan oleh Bank Indonesia merupakan negara OECD pemberi pinjaman terbanyak. Selain itu, Jepang juga menerapkan pendekatan earning stripping rules yaitu alternatif pendekatan fixed ratio selain yang direkomendasikan dalam BEPS Action Plan 4.

c. Afrika Selatan dipilih karena memiliki beberapa kesamaan, yaitu merupakan negara berkembang dan juga merupakan negara partner OECD yang tarif pajak korporasinya $28 \%$, tidak jauh berbeda dengan Indonesia yang tarifnya 25\%. Baik Afrika Selatan maupun Indonesia tarif pajak korporasinya di atas tarif rata-rata global, 23,63\% versi KPMG.

d. China dipilih karena sama-sama tergabung dalam G20 dan memiliki tarif pajak korporasi sama dengan Indonesia, yaitu $25 \%$.

e. Inggris dipilih karena pernah terjadi kasus penghindaran pajak seperti Starbucks, yang salah satu materinya terkait intercompany loan. Starbucks untuk membayar denda pajaknya.

Metode ketiga ini untuk memberikan gambaran bagaimana praktis penggerusan basis pemajakan dan pergeseran laba di Indonesia, kemudian membandingkan pendekatan fixed ratio yang digunakan berdasarkan peraturan yang berlaku saat ini di Indonesia dengan pendekatan yang direkomendasikan dalam BEPS Action Plan 4. Datadata yang digunakan bersumber dari Direktorat Jenderal Pajak. yang dikategorikan dalam 2 data, yaitu data wajib pajak yang melaporkan rugi selama 5 tahun berturut-turut dan data pelaporan perpajakan tahun 2015. 
a. Data wajib pajak yang melaporkan rugi 5 tahun berturut-turut

Untuk mengetahui gambaran praktik penggerusan basis pemajakan oleh wajib pajak dapat dilihat melalui komponen biaya pada Wajib Pajak (WP) mengalami kerugian dan 5 tahun berturut-turut dan tidak pernah membayar pajak. Dalam pembahasan, sumber data berasal dari DJP dengan sampel dari tahun 2011 s.d. 2015 dan kriteria WP Badan tersebut melaporkan rugi selama 5 tahun berturut-turut serta terdaftar di Kantor Pelayanan Pajak (KPP) di lingkungan Kantor Wilayah (Kanwil) Besar, Kanwil DJP Jakarta Khusus, dan seluruh KPP Madya di Indonesia, dengan total 32 KPP. KPP tersebut dipilih karena penerimaan PPh Badan dari KPP tersebut mewakili lebih dari $70 \%$ penerimaan pajak per tahun 2015. Selanjutnya, dikurangi dengan data WP yang dikecualikan dari PMK 169/PMK.010/2015 berdasarkan kode Klasifikasi Lapangan Usaha (KLU) dalam KEP-321/PJ/2012 dan WP dengan rasio interest to EBITDA-nya kurang dari atau sama dengan nol, karena berdasarkan Lampiran B BEPS Action Plan 4, WP dengan EBITDA negatif dikecualikan dalam melihat pengaruh fixed ratio yang direkomendasikan dalam BEPS Action Plan 4. Dari 9.444 data yang tersedia, hanya 380 sampel (76 WP per tahun) data yang dapat digunakan dalam penelitian.

b. Data pelaporan perpajakan tahun 2015

Data sampel yang digunakan untuk mengetahui potensi penerapan BEPS Action Plan 4 dalam mengatasi BEPS di Indonesia, dipilih berdasarkan kriteria sebagai berikut. Dari seluruh data WP yang terdaftar aktif di DJP per 31 Desember 2015, hanya dipilih data WP pada Kantor Pelayanan Pajak (KPP) yang telah melaporkan SPT Tahun 2015 dan datanya ter-input dalam sistem informasi perpajakan DJP. Kemudian, data tersebut dikurangi data yang tidak lengkap, DERnya kurang dari atau sama dengan nol, dan juga kriteria pengurangan pada huruf a. Dari 28.995 data, hanya 2.568 yang dapat dilakukan observasi.

\section{Hasil dan Pembahasan}

Tinjauan Literatur atas Aspek-Aspek dalam BEPS Action Plan 4

Pembatasan interest deductions and other financial payments merupakan amanat dari Pasal 18 ayat (1) UU PPh yang diatur lebih lanjut dalam Pasal 2 PMK 169/PMK.010/2015. Pembatasan tersebut menerapkan pendekatan dengan basis rasio yang tetap (fixed ratio) dengan mengacu pada tingkat DER paling tinggi 4:1. Ambang batas ini lebih longgar dari peraturan sebelumnya (KMK.1002/KMK.04/1984) yang batasnya hanya 3:1. Keputusan tingkat DER 4:1 merupakan hasil dari pengamatan yang dilakukan BKF. Responden dari BKF menyebutkan bahwa hasil pengamatan BKF menunjukkan bahwa pada umumnya kondisi usaha memiliki ambang batas DER 3:1. Namun untuk meminimalisasi ketidaksiapan pihak swasta, maka diputuskan untuk melonggarkan ambang batas DER menjadi $4: 1$.

Selain ambang batas yang lebih longgar, kemudahan lainnya yaitu dengan penghitungan dan pelaporan yang sederhana. Responden perwakilan BKF menjelaskan bahwa penyederhanaan peraturan ini dimaksudkan untuk tidak menyulitkan atau terlalu membatasi calon investor sehingga mereka tetap tertarik untuk berinvestasi dan berbisnis di Indonesia.

Kelonggaran ambang batas DER 4:1 dikhawatirkan dapat menimbulkan terjadinya moral hazard. Kurniawan (2016) menyatakan bahwa dengan adanya kelonggaran 4:1 ini memiliki moral hazard tersendiri, dimana perusahaan dengan tingkat DER masih di bawah ambang batas merasa masih memiliki kesempatan untuk menambah pendanaannya melalui utang, sedangkan perusahaan yang sudah mencapai ambang batas, mempunyai kesempatan untuk memainkan interest rate kepada pihak yang memiliki hubungan istimewa, agar dapat mengurangi penghasilan kena pajaknya.

Selain itu, pembatasan tersebut juga memperhatikan biaya yang dapat atau tidak dapat dikurangkan yang berkaitan dengan kegiatan untuk menghasilkan, menagih dan memelihara pendapatan, sebagaimana tertuang dalam Pasal 6 dan Pasal 9 UU $\mathrm{PPh}$. Demikian halnya untuk perjanjian utang antara pihak yang memiliki hubungan istimewa, utang tersebut juga harus memenuhi prinsip kewajaran dan kelaziman usaha (arm's length principle) sebagaimana diatur dalam Pasal 18 ayat (3) UU PPh.

Dengan menggunakan saldo rata-rata bulanan, definisi utang dan modal dalam PMK 169/PMK.010/2015 lebih relevan dan adil daripada KMK 1002/KMK/1984. Selain itu, konsep penghitungan DER yang sederhana juga memudahkan wajib pajak dalam menghitung penghasilan kena pajaknya.

Pengecualian terhadap wajib pajak baru diatur dalam Pasal 2 ayat (2) PMK-169/PMK.010/2015, karena tidak ada pengecualian pada peraturan 
sebelumnya. Wajib pajak tersebut dikecualikan karena telah memiliki aturan khusus (lex specialis), diatur secara ketat (highly regulated) atau diawasi oleh otoritas tertentu, seperti halnya Otoritas Jasa Keuangan (OJK) untuk mengawasi bank, lembaga pembiayaan, asuransi dan reasuransi.

Darussalam dan Kristiaji (2015) menyebutkan bahwa pengukuran aktivitas ekonomi dalam PMK 169/010.2015 menggunakan pos-pos debt dan ekuitas yang berbasis pada balance sheet. Pengukuran ini dinilai kurang efektif untuk membatasi biaya yang ada pada income statement (interest expense) karena tidak berhubungan langsung dengan penghasilan kena pajak. Sebagaimana diketahui, penghasilan kena pajak sangat dipengaruhi dari perkiraan pada laporan laba rugi. Hal ini didukung dengan adanya beberapa negara yang sudah mulai mengarah pada pendekatan berbasis income statement.

Dengan definisi bunga yang jelas, diharapkan dapat mengatasi praktik BEPS yang menggerus basis pemajakan dan menggeser laba melalui berbagai macam bentuk instrumen. Wiratama (2016) dan Kurniawan (2016) menyatakan bahwa pendefinisian biaya bunga dalam PMK 169/PMK.010/2015 sudah lebih rinci daripada peraturan yang sebelumnya, termasuk biaya-biaya lainnya yang ekuivalen dengan biaya bunga. Darussalam dan Kristiaji (2015) juga mendukung pernyataan tersebut.

Ditinjau dari tujuan peraturan, PMK 169/PMK.010/2015 telah mengalami banyak perkembangan dibandingkan peraturan sebelumnya. Walaupun rasio yang ditetapkan lebih longgar daripada KMK 1002/KMK.04/1984, PMK 169/PMK.03/2015 mempunyai tujuan yang sama, yaitu untuk menunaikan amanat dari Pasal 18 ayat (1) UU PPh, membatasi perbandingan utang atas modal yang melebihi batas kewajaran sehingga menggerus basis pemajakan melalui biaya bunga yang berlebihan. Di samping itu, PMK 169/PMK.03/2015 diharapkan dapat memengaruhi struktur permodalan wajib pajak, sehingga utang luar negeri sektor swasta secara optimal diperuntukkan untuk ekspansi bisnis.

Setiap entitas memiliki kesempatan yang sama untuk melakukan praktik BEPS ini. Dengan demikian, pengecualian yang diberlakukan pada industri perbankan, lembaga pembiayaan, asuransi dan reasuransi dianggap mencederai rasa keadilan, sebagaimana yang dikemukakan oleh Darussalam dan Kristiaji (2015). Hal ini didasarkan pada pertimbangan bahwa sampai saat ini Indonesia belum menerapkan ketentuan khusus untuk membatasi biaya bunga yang berlebihan pada entitas tersebut.
Perbandingan Aspek-aspek dalam BEPS Action Plan 4 Terhadap Peraturan Pembatasan Interest Deductions and Other Financial Payments

Pendekatan pembatasan interest deductions and other financial payments yang digunakan untuk mengatasi BEPS dalam peraturan di Indonesia masih terlalu sederhana dan tidak langsung membatasi biaya bunga. Hal ini dapat dipahami karena PMK 169/PMK.03/2015 tidak difokuskan untuk membatasi biaya bunga, tetapi untuk membatasi rasio utang terhadap modal. Sampai saat ini, Indonesia belum memiliki dasar hukum yang kuat untuk menggunakan interest expense to EBITDA ratio dan melaksanakan rekomendasi BEPS Action Plan 4. Namun, hal tersebut tidak menutup kemungkinan Indonesia untuk menggunakan pendekatan rasio tersebut. Pendekatan dalam BEPS Action Plan 4 masih dapat diterapkan melalui amandemen UU PPh yang sampai saat ini masih menjadi wacana.

Proses amandemen peraturan perpajakan juga sedang ditempuh oleh Inggris untuk dapat mengadopsi BEPS Action Plan 4 per 1 April 2017. Hal tersebut merupakan wujud komitmen Inggris untuk melaksanakan best practice tersebut. Berbeda halnya dengan Inggris, China menolak untuk mengadopsi BEPS Action Plan 4, karena enggan mengamademen peraturan perpajakannya. Sementara itu, Australia, Jepang dan Afrika Selatan sudah mengadopsi sebagian pendekatan dari BEPS Action Plan 4.

Perbedaan perlakuan peraturan perpajakan di masing-masing negara menjadi loophole bagi isu perpajakan internasional. Entitas akan lebih memilih peraturan perpajakan yang favourable bagi bisnisnya. Untuk meminimalisasi loophole yang menggerus basis pemajakan suatu negara, diperlukan harmonisasi peraturan perpajakan antar negara tersebut. Perlakuan yang sama diberikan kepada wajib pajak dan prinsip keadilan, sebagaimana asas perpajakan internasional, dapat terwujud.

Berdasarkan peninjauan definisi debt sebagai elemen rasio di atas, diketahui bahwa penggunaan saldo rata-rata dalam penghitungan debt sudah berlaku secara umum dan diterapkan oleh negaranegara yang ditinjau. Definisi debt tersebut mempersempit celah untuk menghindari pajak melalui pengaturan struktur modal di akhir tahun untuk menjaga rasio solvabilitas. Lain halnya dengan definisi ekuitas. Setiap negara umumnya telah mendefinisikan ekuitas dalam arti yang luas berdasarkan OECD (2012), yaitu meliputi modal 
saham, setoran modal, laba ditahan, pinjaman tanpa bunga, dan cadangan revaluasi. Tetapi, penggunaan saldo rata-rata dalam penghitungan ekuitas hanya diberlakukan di Indonesia. Sehingga, penghitungan DER di Indonesia lebih relevan dan adil, meskipun belum tentu favourable bagi wajib pajak. Hal ini dikarenakan, favourable atau tidak tergantung dari kondisi ekuitas wajib pajak tersebut.

Kemudian, setiap negara berbeda dalam menentukan entitas yang diberlakukan dan dikecualikan dalam peraturan pembatasan interest deductions and other financial payments. Indonesia mengecualikan industri berdasarkan risiko entitasnya, yaitu dikecualikan ketika entitas dianggap memiliki peraturan yang bersifat lex specialis, highly regulated ataupun diawasi oleh banyak pihak. Sementara itu, negara OECD dan G20 lainnya menentukan entitas yang diberlakukan dan dikecualikan dalam peraturan tersebut berdasarkan risiko transaksi yang dilakukan oleh entitas tersebut, sehingga pembatasan biaya bunga dikecualikan pada entitas yang berisiko rendah untuk melakukan transaksi biaya bunga yang berlebihan, baik kepada pihak yang memiliki hubungan istimewa atau pun pihak ketiga. Oleh karena itu, Afrika Selatan tidak memberikan pengecualian pada industri tertentu karena entitas dianggap memenuhi kriteria yang berisiko rendah sepanjang menggunakan interest rate yang sesuai dengan prinsip kewajaran dan kelaziman usaha.

BEPS Action Plan 4 merekomendasikan pengukuran aktivitas ekonomi berdasarkan income statement karena dianggap dapat lebih tegas mencegah penghindaran pajak. Apabila entitas menggunakan pinjaman dengan biaya bunga yang tinggi, agar dapat membiayakan semua biaya bunganya, maka entitas tersebut harus meningkatkan juga earning-nya. Dengan demikian, entitas tidak mempunyai jalan lain selain menyesuaikan biaya bunganya dengan kemampuan pendapatannya. Pengukuran berbasis income statement tersebut diterapkan di Inggris dan Afrika Selatan. Sedangkan tiga dari enam negara, yaitu Australia, China dan Indonesia masih menggunakan pengukuran berbasis balance sheet. Hanya Jepang yang menggunakan kombinasi antara pengukuran income statement dan balance sheet. Pendekatan income statement dinilai akan lebih efektif karena langsung membidik pembebanan biaya bunga yang melebihi kemampuan ekonomis entitas dalam menghasilkan pendapatan.

Rekomendasi BEPS Action Plan 4 mendefinisikan biaya bunga dan biaya lainnya yang setara dengan biaya bunga dengan sangat rinci, termasuk biaya setara bunga yang berlandaskan konsep Syariah.
Untuk definisi ini bertentangan dengan konsep syariah yang dikenal di Indonesia, yang tidak mengenal pembayaran yang berlebih dari pinjam meminjam, sehingga Indonesia akan kesulitan untuk menerapkan rekomendasi ini karena akan mencederai konsep syariah yang ada. Namun, secara keseluruhan Indonesia telah mendefinisikan biaya bunga yang dibatasi dengan rinci. Begitu juga dengan negara lainnya, kecuali Afrika Selatan yang menggunakan definiskan biaya bunga lebih luas.

Sebagaimana yang diusulkan dalam BEPS Action Plan 4, peraturan pembatasan biaya bunga bertujuan untuk membatasi biaya bunga berlebihan dari transaksi khusus, begitu juga dengan Indonesia dan negara lainnya walaupun beda penekanan pada praktik penghindaran pajaknya. Selain itu, BEPS Action Plan 4 juga merekomendasikan untuk adanya koordinasi dengan peraturan yang khusus dalam mengatasi penghindaran pajak. Indonesia, Jepang, dan China belum memiliki peraturan khusus yang terintegrasi. Sedangkan Australia, dan Afrika Selatan sudah menerapkan peraturan yang terintegrasi dengan peraturan lainnya, begitu juga dengan Inggris yang berkomitmen untuk menyusun peraturan khusus terkait.

Potensi Penerapan BEPS Action Plan 4 dalam Mengatasi Base Erosion and Profit Shifting di Indonesia

Berdasarkan Tabel 1 diketahui bahwa terdapat wajib pajak yang melaporkan rugi selama 5 tahun berturut-turut. Dari 76 sampel perusahaan yang digunakan dalam penelitian ini, rata-rata $26 \%$ perusahaan memiliki biaya bunga yang lebih dari laba operasionalnya sebelum biaya bunga, pajak, depresiasi dan amortisasi. Hal ini ditunjukkan dengan rasio biaya bunga terhadap EBITDA-nya yang lebih dari $100 \%$.

EBITDA yang digunakan dalam penghitungan tersebut adalah EBITDA berdasarkan fiskal, yaitu dengan menambahkan kembali biaya penyusutan dan biaya bunga pada penghasilan kena pajak. Sedangkan interest expense yang digunakan adalah biaya bunga pinjaman tanpa dikurangi dengan pendapatan bunga. Diasumsikan pendapatan bunga merupakan objek pajak penghasilan final sehingga tidak dimasukkan dalam penghitungan biaya bunga bersih sebagaimana yang direkomendasikan dalam BEPS Action Plan 4. Wajib pajak yang memiliki biaya bunga lebih dari $100 \%$ laba operasi sebelum bunga, depresiasi, amortisasi dan pajak, mengindikasikan adanya 
praktik pergeseran laba melalui biaya bunga yang berlebihan. Hal ini dikarenakan sumber kerugian wajib pajak bukan berasal dari aktivitas operasinya, melainkan dari komponen biaya bunga dan biaya lain-lain. Indikasi adanya praktik penggerusan basis pemajakan di Indonesia ini semakin kuat didukung dengan adanya perbedaan tarif pajak korporasi di Indonesia dibandingkan negara-negara ASEAN (Lihat Gambar 1). Di antara negara ASEAN, Indonesia yang memiliki tarif pajak korporasi yang tinggi. Namun, bila dibandingkan dengan beberapa negara-negara OECD dan G20 yang dijadikan sampel dalam penelitian ini, tarif pajak korporasi Indonesia masih lebih rendah.

Tabel 1

Persentase WP yang Interest Expense to EBITDA Ratio Pada Perusahaan Rugi Selama 5 Tahun Berturut-Turut (2011 s.d. 2015)

\begin{tabular}{|c|c|c|c|c|c|c|}
\hline \multirow{2}{*}{$\begin{array}{c}\text { Interest } \\
\text { Expense to } \\
\text { EBITDA ratio }\end{array}$} & \multicolumn{6}{|c|}{ Persentase Wajib Pajak } \\
\hline & 2011 & 2012 & 2013 & 2014 & 2015 & $\begin{array}{c}\text { Rata- } \\
\text { rata }\end{array}$ \\
\hline $0-10 \%$ & $50 \%$ & $54 \%$ & $50 \%$ & $49 \%$ & $45 \%$ & $49 \%$ \\
\hline$>10 \%-20 \%$ & $11 \%$ & $7 \%$ & $8 \%$ & $9 \%$ & $12 \%$ & $9 \%$ \\
\hline$>20 \%-30 \%$ & $3 \%$ & $4 \%$ & $7 \%$ & $4 \%$ & $4 \%$ & $4 \%$ \\
\hline$>30 \%-40 \%$ & $1 \%$ & $0 \%$ & $1 \%$ & $3 \%$ & $5 \%$ & $2 \%$ \\
\hline$>40 \%-50 \%$ & $3 \%$ & $3 \%$ & $1 \%$ & $1 \%$ & $3 \%$ & $2 \%$ \\
\hline$>50 \%-60 \%$ & $4 \%$ & $0 \%$ & $1 \%$ & $4 \%$ & $1 \%$ & $2 \%$ \\
\hline$>60 \%-70 \%$ & $1 \%$ & $5 \%$ & $4 \%$ & $0 \%$ & $1 \%$ & $2 \%$ \\
\hline$>70 \%-80 \%$ & $1 \%$ & $4 \%$ & $1 \%$ & $1 \%$ & $0 \%$ & $2 \%$ \\
\hline$>80 \%-90 \%$ & $0 \%$ & $0 \%$ & $0 \%$ & $0 \%$ & $0 \%$ & $0 \%$ \\
\hline$>90 \%-100 \%$ & $0 \%$ & $0 \%$ & $1 \%$ & $3 \%$ & $0 \%$ & $1 \%$ \\
\hline$>100 \%$ & $26 \%$ & $24 \%$ & $25 \%$ & $26 \%$ & $29 \%$ & $26 \%$ \\
\hline Observasi & 76 & 76 & 76 & 76 & 76 & 76 \\
\hline
\end{tabular}

Kompetisi tarif pajak antar negara merupakan hal yang wajar. Dengan tarif pajak yang lebih tinggi dibandingkan negara sekitar berpotensi terjadinya penggeseran pendapatan yang diterima dari Indonesia ke negara sekitar yang memiliki tarif pajak lebih rendah. Pergeseran tersebut dilakukan baik melalui skema transfer picing maupun skema debt shifting. Agar basis pemajakan di dalam negeri tidak digeser ke negara yang tarif pajaknya lebih rendah, diperlukan Tax Treaty dan pendekatan yang fokus pada pencegahan praktik tersebut.

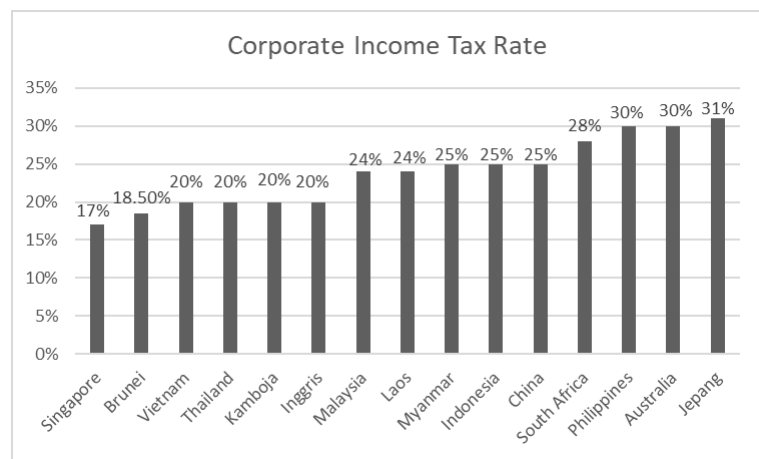

Sumber: berbagai sumber, diolah sendiri Gambar 1. Corporate Income Tax Rate di ASEAN, Beberapa
Negara OECD dan G20

Walaupun sama-sama menggunakan pendekatan FRR, PMK 169/PMK.010/2015 berbasis balance sheet, sedangkan BEPS Action Plan 4 berbasis income statement. Perbedaan basis dan juga rasio yang digunakan akan memberikan hasil yang berbeda. Hal ini dapat ditunjukkan dengan melihat potensi saat PMK 169/PMK.010/2015 dan BEPS Action Plan 4 tersebut yang disimulasikan penerapannya pada tahun pajak 2015 (Lihat Tabel 2).

Tabel 2

Persentase Pengaruh Batasan DER pada Wajib Pajak

\begin{tabular}{ccc}
\hline & \multicolumn{2}{c}{ Jumlah WP Tahun 2015 } \\
\cline { 2 - 3 } Batas DER & $\begin{array}{c}\text { Persentase } \\
\text { yang } \\
\text { Memenuhi } \\
\text { Batas }\end{array}$ & $\begin{array}{c}\text { Kenaikan } \\
\text { Persentase }\end{array}$ \\
\hline $4: 1$ & $86 \%$ & NA \\
$5: 1$ & $89 \%$ & $3 \%$ \\
$6: 1$ & $91 \%$ & $2 \%$ \\
$7: 1$ & $93 \%$ & $2 \%$ \\
$8: 1$ & $94 \%$ & $1 \%$ \\
$9: 1$ & $95 \%$ & $1 \%$ \\
$10: 1$ & $96 \%$ & $1 \%$ \\
$>10: 1$ & $100 \%$ & $4 \%$ \\
Observasi & 2568 \\
\hline Sumber: Direktorat Jenderal Pajak, diolah sendiri
\end{tabular}

Karena keterbatasan data, diasumsikan bahwa sepanjang tahun nilai debt dan equity tetap. Nilai rata-rata utang dan modal didapatkan dari saldo tahun sebelumnya dan saldo tahun pajak 2015. Dari 2.568 observasi, $86 \%$ wajib pajak sudah memenuhi ketentuan ambang batas DER berdasarkan PMK 169/PMK.010/2015. Hanya sekitar 14\% dari observasi yang akan terpengaruh dengan ambang batas DER tersebut. Terlihat bahwa kenaikan persentase pada DER yang lebih dari 4:1 terus 
menurun dan kembali naik menyentuh angka $4 \%$ atau sekitar 115 wajib pajak ketika DER lebih dari 10:1. Hal ini mengindikasikan bahwa terdapat wajib pajak yang masih mengandalkan utang sebagai sumber operasionalnya, bahkan 10 kali melebihi modalnya.Untuk mendapatkan gambaran lebih lanjut berapa sebesar porsi biaya bunga pinjaman yang dibayarkan perusahaan dengan DER lebih dari 10, digunakan interest expense to EBITDA Ratio yang hasilnya dapat dilihat pada Tabel 3.

Tabel 3

Persentase Interest Expense to EBITDA Ratio pada Wajib Pajak yang Memiliki DER Lebih dari 10:1

\begin{tabular}{cc}
\hline $\begin{array}{c}\text { Batas Interest Expense to } \\
\text { EBITDA Ratio }\end{array}$ & 2015 \\
\hline $10 \%$ & $33 \%$ \\
$20 \%$ & $6 \%$ \\
$30 \%$ & $5 \%$ \\
$40 \%$ & $6 \%$ \\
$50 \%$ & $10 \%$ \\
$60 \%$ & $15 \%$ \\
$70 \%$ & $7 \%$ \\
$80 \%$ & $11 \%$ \\
$90 \%$ & $3 \%$ \\
$100 \%$ & $4 \%$ \\
Observasi & 115 \\
\hline
\end{tabular}

Sumber: Direktorat Jenderal Pajak, diolah sendiri

Banyaknya utang tidak menjamin bahwa perusahaan memiliki biaya bunga yang berlebihan. Dari Tabel 3 terlihat bahwa dari 115 wajib pajak yang memiliki DER-nya lebih dari 10, 32\%-nya memiliki porsi biaya bunga hanya $10 \%$ dari EBITDA-nya dan hanya 4\%-nya memiliki biaya bunga lebih dari 100\% EBITDA.

Besarnya biaya bunga tidak dipengaruhi oleh banyaknya utang, tetapi oleh suku bunganya. Dengan demikian, dapat dikatakan bahwa pendekatan dengan rasio DER kurang efektif untuk membatasi biaya bunga yang berlebihan. Oleh karena itu, tersedia alternatif lain untuk menggunakan pendekatan berdasarkan interest expense to EBITDA ratio. Pendekatan ini merupakan best practice yang direkomendasikan oleh OECD dan G20 dalam mengatasi BEPS. Dengan adanya fakta bahwa di Indonesia berpotensi terdapat penggerusan basis pemajakan melalui praktik BEPS ini, perlu dilihat lebih lanjut potensi dari best practice ini diadopsi di Indonesia. Pengaruh pendekatan ini dapat dilihat pada Tabel 4.

Tabel 4

Persentase Pengaruh Interest to EBITDA Ratio pada Wajib Pajak

\begin{tabular}{cc}
\hline $\begin{array}{c}\text { Batas Interest Expense to } \\
\text { EBITDA Ratio }\end{array}$ & 2015 \\
\hline $10 \%$ & $39 \%$ \\
$20 \%$ & $29 \%$ \\
$30 \%$ & $21 \%$ \\
$40 \%$ & $14 \%$ \\
$50 \%$ & $10 \%$ \\
$60 \%$ & $6 \%$ \\
$70 \%$ & $4 \%$ \\
$80 \%$ & $3 \%$ \\
$90 \%$ & $2 \%$ \\
$100 \%$ & $2 \%$ \\
Observasi & 2568 \\
\hline Sumber: Direktur Jenderal Pajak, diolah sendiri
\end{tabular}

Dalam BEPS Action Plan 4, untuk membatasi biaya bunga yang berlebihan dalam penghitungan penghasilan kena pajak dapat menggunakan interest expense to EBITDA ratio dengan batas $10 \%$ s.d. $30 \%$. Semakin tinggi batas interest expese to EBITDA ratio yang diterapkan, akan semakin sedikit WP yang terpengaruh.

Berdasarkan Tabel 4 tersebut terlihat bahwa terdapat sekitar 2\% Wajib Pajak atau sekitar 40 dari 2.568 observasi yang memiliki biaya bunga di atas EBITDA-nya. Apabila dibuat rinci, DER wajib pajak pada tingkat batas interest expense to EBITDA lebih dari $100 \%$, diketahui bahwa walaupun interest expense wajib pajak melebihi EBITDA-nya, DER yang dimiliki wajib pajak tersebut masih dalam ambang batas 4:1 (lihat Tabel 5).

Dari uraian di atas diperoleh gambaran bahwa rasio DER yang saat ini diterapkan di Indonesia masih belum memadai untuk mengatasi biaya bunga yang berlebihan. Oleh karena itu, diperlukan kombinasi tambahan dengan menggunakan pendekatan best practice agar dapat lebih ketat dalam membatasi biaya bunga yang berlebihan. Hal ini dikarenakan DER membatasi biaya bunga secara tidak langsung, sedangkan interest expense to EBITDA ratio dapat langsung membidik pada biaya yang berlebihan pada penghasilan kena pajaknya. 
Tabel 5.

DER Wajib Pajak yang Memiliki Interest Expense to EBITDA Ratio Lebih dari $100 \%$

\begin{tabular}{cc}
\hline DER & 2015 \\
\hline$<4: 1$ & $73 \%$ \\
$\geq 4: 1$ s.d $5: 1$ & $10 \%$ \\
$\geq 5: 1$ s.d $6: 1$ & $3 \%$ \\
$\geq 6: 1$ s.d $7: 1$ & $3 \%$ \\
$\geq 10: 1$ & $13 \%$ \\
\hline Total & 40
\end{tabular}

Sumber: Direktorat Jenderal Pajak, diolah sendiri

Kedua pendekatan tersebut harus dikombinasikan untuk saling mengatasi kelemahannya masingmasing. Kelemahan dari pendekatan yang berbasis income statement yang dipengaruhi oleh pertumbuhan ekonomi dapat diantisipasi dengan pendekatan DER yang lebih stabil. Begitu juga dengan kelemahan pendekatan berbasis balance sheet yang membatasi biaya bunga secara tidak langsung dapat diantisipasi dengan pendekatan berbasis income statement yang membatasi biaya bunga yang berlebihan secara langsung.

Kurniawan (2016) dan Wiratama (2016) mendukung pernyataan di atas. Mereka menyatakan bahwa untuk memfokuskan pembatasan biaya bunga yang berlebihan di Indonesia, tidak cukup dengan pendekatan pembatasan utang terhadap modal. Pendekatan tersebut perlu dilengkapi dengan interest expense to EBITDA ratio. Selain itu, dengan diterapkannya interest to EBITDA ratio tersebut juga dapat menyederhanakan pendekatan arm's length principle berdasarkan pasal 18 ayat (3) UU PPh.

Kombinasi pendekatan dengan menggunakan GRR tidak direkomendasikan untuk diterapkan di Indonesia saat ini mengingat pendekatan tersebut membutuhkan keterbukaan informasi. Sementara itu, administrasi perpajakan di Indonesia masih belum siap untuk keterbukaan tersebut. Belum lagi untuk mendapatkan data perpajakan dari perusahaan group yang memerlukan arus pertukaran informasi data dengan negara lain bukan hal yang mudah. Hal tersebut menjelaskan bahwa GRR belum dapat diterapkan di Indonesia.

Berdasarkan pembahasan di atas, dapat digambarkan bahwa dengan diadopsinya BEPS Action Plan 4 di Indonesia dan dikombinasikan dengan pembatasan DER yang berlaku saat ini, akan lebih efektif dalam membatasi interest deductions and other financial payments yang sifatnya merugikan bagi basis pemajakan di Indonesia.

Harmonisasi peraturan perpajakan dapat dilakukan dengan mengadopsi perlakuan perpajakan yang sama, salah satunya dengan mengadopsi BEPS Action Plan 4 ini, sebagai upaya membatasi penghindaran pajak. Namun, bukan berarti harus mengenakan tarif pajak yang sama. Hal ini dikarenakan, salah satu cara untuk menstimulus perekonomian bagi suatu negara dilakukan melalui tarif pajak sehingga kompetisi tarif antar negara tidak dapat dihindari. Walaupun ke depannya setiap negara tetap memberikan tarif pajak yang berbeda, perbedaan tarif pajak masih dapat disiasati dengan adanya tax treaty antar negara.

\section{Kesimpulan}

Secara keseluruhan, peraturan terkait pembatasan interest deductions and other financial payments di Indonesia telah dikembangkan dengan baik dibandingkan peraturan sebelumnya dan tetap memperhatikan simplifikasi administrasi perpajakan melalui pendekatan yang sederhana. Peraturan pembatasan tersebut telah memenuhi 6 dari 7 kategori aspek yang ditinjau dalam BEPS Action Plan 4. Walaupun masih menggunakan pendekatan yang berbeda, akan tetapi sudah mewakili aspekaspek tersebut. Kecuali, aspek adanya ketentuan khusus yang terkait. Hal ini dikarenakan Indonesia belum memiliki aturan yang terintegrasi dengan peraturan lainnya terkait pembatasan tersebut.

Setelah membandingkan aspek-aspek BEPS Action Plan 4 terhadap peraturan pembatasan interest deductions and other financial payments yang berlaku di Indonesia, negara-negara OECD dan G20 lainnya serta best practice yang direkomendasikan oleh OECD dan G20, dapat disimpulkan bahwa aspek-aspek dalam BEPS Action Plan 4 diterapkan oleh Indonesia, Australia, Jepang, Afrika Selatan, dan Inggris dengan penyesuaian berdasarkan karakteristik masing-masing negara. Bahkan Inggris berkomitmen untuk mengadopsi BEPS Action Plan 4 secara penuh mulai efektif per 1 April 2017. Sementara itu, walaupun menolak untuk mengadopsi BEPS Action Plan 4 karena enggan untuk mengamandemen peraturan perpajakannya, China memenuhi aspek dalam BEPS Action Plan 4 dengan pendekatan yang berbeda.

Keunggulan peraturan yang dimiliki Indonesia dibandingkan negara-negara OECD dan G20 lainnya serta best practice yang direkomendasikan oleh 
OECD dan G20 adalah peraturan tersebut masih sangat sederhana sehingga memudahkan Wajib Pajak dan calon investor untuk memenuhi kewajiban perpajakannya dengan tax compliance cost yang relatif rendah. Pendefinisian elemen yang digunakan di Indonesia sudah memenuhi definisi yang digunakan secara umum. Begitu juga pendefinisikan interest deductions and other financial payment dan tujuan peraturan pembatasan tersebut sudah mengikuti instrumen - instrumen struktur permodalan yang saat ini berkembang.

Kelemahan yang dimiliki peraturan di Indonesia adalah pendekatan yang berlaku di Indonesia dianggap kurang efektif karena masih berbasis balance sheet, sementara biaya bunga berbasis income statement. Hal ini dikarenakan, Indonesia belum mempunyai dasar hukum yang memadai untuk mengadopsi BEPS Action Plan 4. Maka, untuk mengadopsi hal tersebut Indonesia harus mengamandemen UU PPh. Selain itu, terdapat celah dari kekosongan ketentuan khusus terkait pembatasan biaya bunga.

Tingkat DER yang tinggi bukan berarti biaya bunga yang dibebankan berlebihan. Terdapat wajib pajak yang biaya bunganya lebih tinggi dari EBITDA dan memiliki DER yang di bawah ambang batas (4:1). Maka, diperlukan kombinasi antara penerapan pendekatan DER yang dengan fixed ratio dalam BEPS Action Plan 4 agar BEPS melalui praktik pembebanan biaya bunga yang berlebihan dapat diatasi dengan lebih baik di Indonesia.

Penelitian ini memiliki beberapa keterbatasan. Pertama terkait dengan data yang digunakan untuk menggambarkan dampak PMK 169/PMK.010/2015. Penelitian ini menggunakan data untuk tahun pajak 2015. Untuk penelitian selanjutnya disarankan menggunakan data dengan rentang tahun pajak yang lebih lama.

Penelitian ini menggunakan metode wawancara untuk memeroleh pandangan stakeholders terhadap penerbitan PMK 169/PMK.010/2015. Wawancara yang dilakukan masih terbatas, yaitu praktisi, akademisi, dan fiskus. Untuk penelitian selanjutnya disarankan untuk melakukan wawancara dengan wajib pajak agar memeroleh pandangan yang komprehensif mengenai peraturan pajak tertentu.

Keterbatasan berikutnya terkait dengan data saldo bulanan atas utang dan modal yang dimiliki perusahaan. Penelitian ini menghitung DER dengan menggunakan rata-rata modal dan utang berdasarkan saldo akhir tahun sebelumnya dan akhir tahun berjalan. Disarankan agar penelitian selanjutnya menggunakan sampel perusahaan privat dengan data yang memadai.

Pajak penghasilan terkait pembatasan interest deductions and other financial payments dibatasi hanya pada pajak penghasilan badan. Penelitian selanjutnya dapat melakukan analisis perilaku wajib pajak dalam preferensi struktur permodalannya setelah PMK 169/PMK.010/2015 berlaku efektif dengan sampel perusahaan privat, sehingga pajak penghasilan yang dianalisis dapat dikembangkan dengan pajak penghasilan lainnya.

Penelitian ini membuat tinjauan literatur atas peraturan untuk negara-negara OECD dan G20, yang merupakan pencetus dari rencana aksi BEPS. Penelitian selanjutnya, dapat menggunakan sampel negara yang lebih banyak, tidak hanya terbatas pada negara OECD dan G20 saja.

\section{Reference}

Alhusnieka, F. 2011. Analisis Terhadap Ketentuan Anti Tax Avoidance dalam Undang-Undang Nomor 36 Tahun 2008 Sebagai Upaya Pencegahan Penghindaran Pajak Internasional. Tesis. Program Pascasarjana Kajian Ketahanan Nasional Universitas Indonesia. Jakarta.

Bartelsman, E.J. dan R.M.W.J. Beetsma, 2003. Why Pay More? Corporate Tax Avoidance Through Transfer Pricing in OECD Countries. Journal of Public Economics 87: 2225-2252.

Burnett, C. 2015. Interest Deductions and Multinational Enterprises: Goldilocks and the Brave New World. Bulletin for International Taxation (June/July 2015): 326-333.

Christiana, D. 2015. Determinan Praktik Thin Capotalization Listed Companies di Indonesia 2010 - 2013. Skripsi. Universitas Indonesia. Jakarta

Darussalam dan B.B. Kristiaji. 2015. Telaah Konstruktif Debt to Equity Ratio di Indonesia. Danny Darussalam Tax Center.

Direktur Jenderal Pajak. 2012. Perubahan atas Keputusan Direktur Jenderal Pajak Nomor KEP-233/PJ/2012 tentang Klasifikasi Lapangan Usaha. Keputusan Direktur Jenderal Pajak Nomor 321/PJ/2012. Jakarta.

Egger, P., et al. 2009. Corporate Taxation, Debt Financing and Foreign-Plant Ownership. European Economic Review 54: 96-107.

Harisman, K. 2014. Analisis pengaruh tax aggressiveness perusahaan terhadap pengunaan utang perusahaan non-keuangan tahun 2008-2012 di Indonesia. Skripsi. Universitas Indonesia. Jakarta

Hartono. 2014. Analisis penerapan peraturan mengenai besarnya perbandingan antara utang dan modal (debt to equity ratio) untuk keperluan penghitungan pajak di Indonesia. Tesis. Universitas Indonesia. Jakarta

Haufler, A. dan M. Runkel, 2012. Firm's Financial Choices and Thin Capitalization Rules Under Corporate Tax Competition. European Economic Review 56: 1087-1103. 
Jefriando, M. 2016. 2.000 Perusahaan Asing Tak Bayar Pajak, Negara Rugi Rp 500 T. http://finance.detik.com/berita-ekonomibisnis/d-3170629/2000-perusahaan-asing-tak-bayar-pajaknegara-rugi-rp-500-t. 22 Maret 2016.

Kementerian Keuangan. 1984. Penentuan Perbandingan Antara Hutang dan Modal Sendiri Untuk Keperluan Pengenaan Pajak Penghasilan. Keputusan Menteri Keuangan Nomor 1002/KMK.04/1984. Jakarta.

1985. Penundaan Pelaksanaan Keputusan Menteri Keuangan Nomor 1002/KMK.01/1984 tanggal 8 Oktober 1984 tentang Penentuan Perbandingan Antara Hutang dan Modal Sendiri Untuk Keperluan Pengenaan Pajak Penghasilan. Keputusan Menteri Keuangan Nomor 254/KMK.01/1985. Jakarta.

2015. Penentuan Perbandingan Antara Hutang dan Modal Sendiri Untuk Keperluan Pengenaan Pajak Penghasilan. Peraturan Menteri Keuangan Nomor 169/PMK.010/2015. Berita Negara Republik Indonesia Tahun 2015 Nomor 1351. Jakarta.

KPMG. 2010. China Tax Alert: Thin Capitalization Provisions Expanded to Cover Deductibility of Interest Expenses on Loan from Individuals dari www.kpmg.com.cn.

(2015a). China Tax Alert: SAT Solicits Public Comments

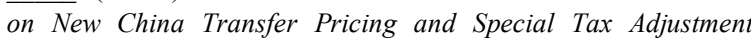
Guidance Discussion Draft dari www.kpmg.com.cn.

Corporate Tax Rate Table diakses pada 27 November 2016 dari https:/home.kpmg.com/xx/en /home/services/tax/tax-toolsand-resources/tax-rates-online/corporate-tax-rates-table.html

(2015b). People's Republic of China Tax Profil dari www.kpmg.com/tax.

(2015c). United Kingdom Country Profile dari www.kpmg.com/tax.

_. (2015d). Taxation in Japan 2015 dari www.kpmg.com/jp/tax $>$.

2016. State Administration of Taxation (SAT) Issued Announcement on the Enhancement of the Reporting of Related Party Transactions and Administration of Contemporaneous Documentation. Dari www.kpmg.com/jp/tax.

OECD. 1986. Report on Thin Capitalization. OECD Publisher.

2012. Thin Capitalization Legislation: A Background Paper of Country Tax Administration. OECD Publisher.

2013a. Addressing Base Erosion and Profit Shifting. Paris. $\overline{\mathrm{OECD}}$ Publishing.

2013b. Action Plan on Base Erosion and Profit Shifting. Paris. OECD Publishing.

2015. Limiting Base Erosion Involving Interest Deductions amd Other Financial Payments, Action 4 - 2015 Final Report
OECD/G20 Base Erosion and Profit Shifting Project. Paris. OECD Publishing.

Peraturan Pemerintah Nomor 94 Tahun 2010 tentang Penghitungan Penghasilan Kena Pajak dan Pelunasan Pajak Penghasilan dalam Tahun Berjalan. 30 Desember 2010. Lembaran Negara Republik Indonesia Tahun 2010 Nomor 161. Jakarta.

Peraturan Presiden Nomor 9 Tahun 2009 tentang Lembaga Pembiayaan. 18 Maret 2009. Jakarta.

Peraturan Presiden Nomor 38 Tahun 2015 tentang Kerja sama Pemerintah Dengan Badan Usaha Dalam Penyediaan Infrastruktur. 20 Maret 2015. Lembaran Negara Republik Indonesia Tahun 2015 Nomor 62. Jakarta.

Prasetyo, A. 2007. Analisis Tax Avoidance Melalui Pinjaman Antar Related Party dan Pencegahannya di Indonesia. Tesis. Universitas Indonesia. Jakarta.

Pricewaterhousecoopers. 2008. Thin Capitalization Ratios. China Tax/Business News Flash dari www.pwc.com.

2013. United Kingdom. International

Transfer Pricing: 792-815 dari www.pwc.com/ internationaltp. . 2015. The People's Republic of China

Tax Facts and Figures dari www.pwc.com. 2016. Worldwide Tax Summaries -

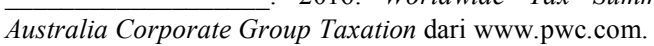
2016. Worldwide Tax Summaries Australia Corporate Deductions dari www.pwc.com. 2016. Worldwide Tax Summaries - Japan Corporate Group Taxation dari www.pwc.com.

Saleh, I.T. 2003. Minimalisasi Upaya Penghindaran Pajak Melalui Ketentuan Rasio Utang Terhadap Modal. Tesis. Universitas Indonesia Jakarta.

Siahaan, R.P. 2010. Analisis Kebijakan Penangkal Praktik Thin Capitalization di Indonesia. Tesis. Universitas Indonesia. Jakarta.

Siregar, L. 2007. Analisis Penerapan Thin Capitalization di Indonesia: Studi Kasus pada Perusahaan Masuk Bursa 2005-2006. Tesis. Universitas Indonesia. Jakarta.

Undang-Undang Nomor 6 Tahun 1983 stdd Undang-Undang Nomor 16 Tahun 2009 tentang Ketentuan Umum dan Tata Cara Perpajakan. 25 Maret 2009. Lembaran Negara Republik Indonesia Tahun 2009 Nomor 62. Jakarta.

Undang-Undang Nomor 7 Tahun 1983 stdd Undang-Undang Nomor 36 Tahun 2008 tentang Pajak Penghasilan. 23 September 2008. Lembaran Negara Republik Indonesia Tahun 2008 Nomor 133. Jakarta.

Yoshihiro, M. 2014. Interest Deduction, Corporate Groups and Tax Jurisdictions - A Hitchhiker's Guide to an Aspect of the BEPS Project. Asia Pacific Tax Bulletin (March/April): 103-107. 